KRZYSZTOF BORODA

Instytut Historii i Nauk Politycznych Uniwersytetu w Białymstoku

Instytut Historii Polskiej Akademii Nauk

\title{
DROBNA SZLACHTA W KRÓLESTWIE POLSKIM \\ W DRUGIEJ POŁOWIE XVI WIEKU I JEJ ZNACZENIE SPOEECZNO-GOSPODARCZE
}

Zarys treści: W artykule omówiono zagadnienie znaczenia drobnej szlachty w strukturach społecznych i ekonomicznych stanu szlacheckiego wczesnonowożytnego Królestwa Polskiego. Przeprowadzono analizę danych statystycznych dotyczących liczby zarejestrowanych majątków szlacheckich, opodatkowanego areału ziemi w uprawie własnej i kmiecej oraz potencjalnego areału folwarcznego, uzyskanych z rejestrów podatkowych pięciu województw: krakowskiego, poznańskiego, kaliskiego, łęczyckiego i płockiego.

The content outline: The article deals with the importance of petty nobility within the social and economic structures of the noble estate in the early modern Polish Kingdom. It presents an analysis of statistical data on the number of registered noble estates, taxable land area in own cultivation and that of peasants, and a possible manor area, obtained from tax registers of five provinces (voivodeships): of Cracow, Poznań, Kalisz, Łęczyca, and Płock.

Slowa kluczowe: historia Polski XVI w., szlachta polska XVI w., historia społeczna, historia gospodarcza, struktura majątkowa szlachty, drobna szlachta

Keywords: history of sixteenth-century Poland, sixteenth-century Polish nobility, social history, economic history, wealth structure of the nobility, petty nobility

Pierwszą poważniejszą refleksję nad struktura majątkowa stanu szlacheckiego w nowożytnym Królestwie Polskim zawdzięczamy Adolfowi Pawińskiemu. Publikując w serii wydawniczej pt. Źródła Dziejowe rejestry poborowe z końca XVI w. dla poszczególnych historycznych dzielnic Królestwa (Wielkopolski, Małopolski i Mazowsza), każdorazowo 
poprzedzał je obszernymi wstępami, w których starał się przekazać czytelnikom swoje refleksje dotyczące zawartości wydawanych źródeł. Jednym z omawianych elementów była struktura własności ziemskiej, przy czym był on niekonsekwentny w zakresie stosowanych kryteriów wyodrębniania poszczególnych kategorii majątkowych szlachty, w tym też interesującej nas tutaj szlachty drobnej. W tomie 12 Źródeł Dziejowych, opisując strukturę własności ziemskiej w Wielkopolsce, odrębnie omówił szlachtę posiadająca kmieci i bezkmieca. W odniesieniu do szlachty posiadajacej kmieci zastosował kryterium liczby posiadanych wsi, przy czym nie przeprowadził żadnej analizy wewnętrznej struktury majątkowej tej grupy społecznej. Śledząc tekst podrozdziału, można dojść do wniosku, że pod pojęciem drobnej szlachty, którego to terminu używał w tekście, rozumiał posiadaczy nie więcej niż jednej wsi ${ }^{1}$. Dla szlachty bezkmiecej (zagrodowej), która omówił oddzielnie, posłużył się kryterium liczby łanów. Nie przeprowadził jednak analizy jej struktury majątkowej, a jedynie zamieścił sumaryczne zestawienie liczby opodatkowanych łanów w poszczególnych województwach w 1569 r. i wyliczył średnie nasycenie nimi na 1 milę kwadratowa ${ }^{2}$.

W tomie 14 Źródeł Dziejowych, omawiając strukturę własności szlachty posiadającej kmieci w Małopolsce, nie użył nigdzie pojęcia „drobna szlachta”. Stosował natomiast pojęcia „wielkiej” i „średniej” własności. Posiadaczy 1-2 wsi, których w tomie 12 traktował jako właśnie drobna szlachtę, określił jako najbardziej typowych przedstawicieli stanu szlacheckiego Małopolski, nie użył jednak względem nich żadnego określenia precyzującego ich pozycję społeczna ${ }^{3}$. Z pojęcia „drobnej szlachty" skorzystał natomiast w odniesieniu do szlachty bezkmiecej, dla której - podobnie jak w przypadku Wielkopolski - zestawił sumaryczne dane o liczbie łanów w poszczególnych powiatach. Zrezygnował jednak z wyliczenia nasycenia łanami „zagrodowymi” na milę kwadratowa ${ }^{4}$.

W poświęconym Mazowszu tomie 16, pomijając dane statystyczne, zamieścił jedynie ogólną charakterystykę własności ziemskiej szlachty posiadającej kmieci, zwracając uwagę na brak własności typu magnackiego i na istnienie majątków rozproszonych, obejmujących często kilka

${ }^{1}$ Polska XVI wieku pod względem geograficzno-statystycznym, oprac. A. Pawiński, t. 1: Wielkopolska, Warszawa 1883 (Źródła Dziejowe, 12), s. 138-144. W obrębie tej grupy umieścił posiadaczy jedynie części wsi, stwierdzając, że stanowili oni około $1 / 4$ szlachty drobnej.

2 Tamże, s. 145-152.

${ }^{3}$ Polska XVI wieku pod względem geograficzno-statystycznym, oprac. A. Pawiński, t. 3: Małopolska, Warszawa 1886 (Źródła Dziejowe, 14), s. 62-99.

${ }^{4}$ Tamże, s. 100-109. 
niewielkich, 1-2-łanowych działów, zlokalizowanych w sąsiadujących ze soba wsiach ${ }^{5}$. Przy czym, podobnie jak w przypadku Małopolski, nie użył tu terminu „drobna szlachta”. Dla szlachty bezkmiecej, której tym razem nie zdefiniował jako „drobnej”, podał liczby opodatkowanych łanów w poszczególnych województwach i wyliczył nasycenia nimi na milę kwadratową w poszczególnych powiatach ${ }^{6}$.

W ślad za Adolfem Pawińskim podążył kontynuator jego dzieła, Aleksander Jabłonowski. W poświęconym ziemiom ruskim tomie 18 Źródeł Dziejowych dla własności szlachty posiadajacej kmieci skorzystał ze sposobu grupowania stosowanego przez Pawińskiego w tomie poświęconym Małopolsce, dzieląc dobra szlacheckie na własność wielką (10 wsi lub więcej), średnia (3-9 wsi) oraz drobną (1-2 wsie) $)^{7}$. Szlachtę bezkmieca potraktował, podobnie jak Pawiński, jako odrębną kategorię społeczna, ograniczając się jedynie do stworzenia listy, w której podał nazwiska i herby pojawiających się w rejestrach poborowych rodzin, bez danych $\mathrm{o}$ areale będacej $\mathrm{w}$ ich posiadaniu ziemi ${ }^{8}$.

Prace Pawińskiego i Jabłonowskiego stały się podstawą do przyjęcia przez polską historiografię praktyki posługiwania się liczbą miejscowości przy analizowaniu struktury majątkowej szlachty posiadającej kmieci oraz zwykle odrębnego, opartego na opodatkowanym lub posiadanym areale ziemi uprawnej, analizowania struktury majątkowej szlachty bezkmiecej. W tym schemacie analizy z czasem stosować zaczęto dwie modyfikacje - wśród będącej przedmiotem naszego zainteresowania drobnej szlachty zaczęto wyodrębniać jako oddzielna grupę szlachtę cząstkowa (właścicieli jedynie części wsi), a część badaczy w ślad za Włodzimierzem Dworzaczkiem, obok kryterium liczby posiadanych miejscowości, wprowadzało jako element uzupełniający szacunki wartości majątków oparte na informacjach zawartych w zapisach oprawnych, transakcjach kupna-sprzedaży i zastawach. Czasem uzupełnienie stanowiły informacje o liczbie posiadanych łanów kmiecych i zagrodników9 ${ }^{9}$

5 Polska XVI wieku pod względem geograficzno-statystycznym, oprac. A. Pawiński, t. 5: Mazowsze, Warszawa 1886 (Źródła Dziejowe, 16), s. 61-65.

6 Tamże, s. 66-70.

7 Polska XVI wieku pod względem geograficzno-statystycznym, oprac. A. Jabłonowski, t. 7, cz. 2, Ziemie Ruskie. Ruś Czerwona, Warszawa 1903 (Źródła Dziejowe, 18), s. $272-330$.

8 Tamże, s. 330-353.

9 W. Dworzaczek, Skład społeczny wielkopolskiej reprezentacji sejmowej $w$ latach 1572-1655, „Roczniki Historyczne” 23, 1957, s. 281-310. Jako przykładowe studia można tu wskazać: tenże, Leliwici Tarnowscy. Z dziejów możnowładztwa małopolskiego wiek XIV-XV, Warszawa 1971; W. Urban, Skład społeczny i ideologia sejmiku krakowskiego $w$ l. 1572-1606, PH, t. 44, 1953, z. 3, s. 309-331; J. Malinowska, Stu- 
Na niską efektywność korzystania z metody opartej na analizie liczby miejscowości przy analizowaniu stratyfikacji społeczno-ekonomicznej szlachty zwrócił uwagę swego czasu Andrzej Wyczański w pracy poświęconej uwarstwieniu społecznemu w Polsce XVI w. ${ }^{10}$ Wskazywał on na silne zróżnicowanie wielkości osiedli wiejskich i miejskich oraz na problematyczność wpasowywania do takiego schematu badawczego własności rozproszonej (posiadaczy tylko części jednej wsi czy też kilku działów majątkowych w różnych miejscowościach, a więc szlachty określanej jako cząstkowa), a także majątków szlachty bezkmiecej. Proponował, by dla XVI stulecia - wobec możliwości wykorzystania źródeł skarbowych - w miejsce liczby miejscowości stosować kryterium kwoty podatku uiszczonego w ramach poboru łanowego. Intuicyjnie takie rozwiązanie wydaje się być dużo lepszym narzędziem analizy pozycji społeczno-ekonomicznej właściciela majątku niż liczba osad. Pozwala bowiem na precyzyjniejszą ocenę zamożności, uwzględniającą zróżnicowany poziom obecności w poszczególnych majątkach ludności małorolnej i bezrolnej oraz młynów, karczem i innych elementów infrastruktury wiejskiej. Umożliwia także ujęcie w jednym zbiorze badawczym wszystkich grup szlachty: właścicieli całych wsi, szlachty cząstkowej oraz bezkmiecej. Proponujacc takie rozwiązanie, Andrzej Wyczański wychodził z założenia, że jednolite w skali całego kraju stawki podatkowe nie miały charakteru arbitralnego, lecz były w intencji ustawodawców w jakiś sposób powiązane z potencjałem gospodarczym poszczególnych elementów składających się na majątek szlachecki. Jednak biorąc pod uwagę sposób ustalania stawek podatkowych oraz różnice w opodatkowaniu poszczególnych kategorii ludności wiejskiej i elementów infrastruktury, ich związek z potencjałem gospodarczym wydaje się wątpliwy. Zauważalne jest raczej świadome dbanie o relatywnie niskie opodatkowanie pewnych grup ludności wiejskiej (przede wszystkim kmieci)

dia osadnicze na obszarze powiatu brzezińskiego do połowy XVI wieku, Toruń 2001; Z. Górczak, Rozwój majatków możnowładztwa wielkopolskiego w drugiej połowie XV i poczatkach XVI wieku, Poznań 2007; Z. Guldon, Rozmieszczenie własności ziemskiej na Kujawach w II połowie XVI w., Torun 1964; E. Trzyna, Ziemia sanocka i struktura jej własności feudalnej od połowy XVI do drugiej połowy XVII w., „Rocznik Województwa Rzeszowskiego" 9, 1978, s. 145-184; L. Polaszewski, Własność feudalna w województwie kaliskim w XVI wieku, Poznań 1976; S. Szybkowski, Kujawska szlachta urzędnicza w późnym średniowieczu (1370-1501), Gdańsk 2006; M. Butkiewicz, Dobra szlacheckie w powiecie tykocińskim, Lublin 1998.

${ }_{10}$ A. Wyczański, Uwarstwienie społeczne w Polsce XVI wieku. Studia, Wrocław 1977, s. 9-12. Jedynym, który skorzystał z tego kryterium jako alternatywnego względem liczby miejscowości, był M. Lubczyński, Szlachta powiatu ksiaskiego za ostatnich Jagiellonów. Struktura majatkowa, Warszawa 2016. 
przy jednoczesnym nakładaniu niewspółmiernie wyższych obciążeń na inne ${ }^{11}$. Ponadto właśnie jednolitość stawek podatkowych w skali całego kraju, dająca poczucie obiektywizmu, jest zwodnicza. Eliminuje bowiem całkowicie z pola obserwacji badawczej zmienne uwarunkowania lokalne, wpływające na dochodowość poszczególnych elementów poddanych opodatkowaniu. Pozostawia też poza polem obserwacji niepodlegający opodatkowaniu kluczowy element gospodarczego życia szlachty okresu nowożytnego - folwark. Idealnym rozwiązaniem byłoby w tej sytuacji oparcie się na kryterium dochodu, pozwalającego uwzględnić wpływ na pozycję ekonomiczna rodziny szlacheckiej jej własnego gospodarstwa rolnego. Nie jesteśmy jednak w stanie przy obecnym stanie badań dokładnie ocenić poziomu dochodowości folwarków szlacheckich, na która wpływało wiele czynników, m.in. ich lokalizacja geograficzna, profil produkcyjny, lokalne uwarunkowania handlowe itp. W związku z tym lepszym (choć na pewno niedoskonałym) rozwiązaniem wydaje się być - w miejsce dotąd wykorzystywanej liczby miejscowości lub kwoty zapłaconego podatku - stosowanie areału opodatkowanej ziemi uprawnej jako miernika statusu społeczno-ekonomicznego szlachty. Ziemia uprawiana bezpośrednio przez kmieci stanowiła bowiem w przypadku szlachty folwarcznej źródło bezpośrednich dochodów w postaci czynszu pieniężnego i dających się spieniężyć świadczeń w naturze, ale przede wszystkim dostarczała pańszczyzny sprzężajnej, będącej element kluczowym dla kalkulacji ekonomicznych związanych z funkcjonowaniem większości folwarków. Zakładając istnienie pewnego związku między areałem kmiecym (i dostępną w efekcie pańszczyzna) a rozmiarami folwarku, informacja o areale kmiecym daje pewne wyobrażenie o potencjalnym areale folwarcznym danego majątku. Oczywiście potencjał folwarczny mierzony posiadanym areałem kmiecym niekoniecznie musi być tożsamy z rzeczywistym areałem folwarku, jednak jego oszacowanie daje możliwość przeprowadzenia łącznej analizy struktury majątkowej szlachty posiadającej kmieci i ich niemającej. W przypadku bowiem szlachty bezkmiecej podlegająca opodatkowaniu ziemia uprawna - niezależnie od tego, czy uprawiana samodzielnie przez członków rodziny szlacheckiej, czy też z wykorzystaniem pracowników najemnych i zagrodników - winna być traktowana jako folwark bezkmiecy. Biorąc pod uwagę dotychczasowe ustalenia w zakresie dochodowości i zasad funkcjonowania folwarków szlacheckich, za drobną szlachtę wypada uznać

${ }^{11} \mathrm{~K}$. Boroda, Kmieć, tan czy profit? Co byto podstawa poboru łanowego w XV i XVI wieku?, w: Człowiek wobec miar i czasu w przeszłości, red. P. Guzowski, M. Liedke, Kraków 2007, s. 152-164. 
posiadaczy areału folwarcznego nie większego niż rozmiary przeciętnego folwarku o maksymalnym areale 3,5-4,0 łanów ziemi uprawnej. W przypadku szlachty posiadającej kmieci byłoby to równoznaczne $\mathrm{z}$ majątkiem o wielkości maksymalnie 5 łanów kmiecych ${ }^{12}$. Oczywiście tak zdefiniowana drobna szlachta byłaby grupa niejednorodna wewnętrznie, obejmująca zarówno niewielkie, mające czasem mniej niż 0,25 łanu gospodarstwa szlachty bezkmiecej, funkcjonujące zapewne często na zasadach szlacheckich gospodarstw rodzinnych, poprzez małe folwarki o areale uprawnym 1,5-2,0 łanów (duże gospodarstwa szlachty bezkmiecej lub majątki szlachty posiadającej maksymalnie 1 łan kmiecy), po majątki skupiające 5 łanów kmiecych i wykorzystujące intensywnie pańszczyznę. $\mathrm{W}$ związku z odmiennym zapotrzebowaniem na siłę roboczą i metodami jej pozyskiwania konieczne jest przeprowadzenie analizy poziomu nasycenia majątków drobnoszlacheckich zagrodnikami, z uwzględnieniem różnic $\mathrm{w}$ ich wielkości i faktem posiadania lub nie kmieci. W przypadku gospodarstw szlachty bezkmiecej wydzielić należy:

- gospodarstwa o areale do 0,24 łanu - jednostki gospodarcze niebędące samowystarczalnymi żywnościowo (przy założeniu prowadzenia produkcji zbożowej), których bilans siły roboczej nie wymagałby zatrudniania zewnętrznych pracowników ${ }^{13}$;

- gospodarstwa o areale 0,25-0,99 łanu - jednostki gospodarcze o wielkości zbliżonej do rozmiarów przeciętnych gospodarstw kmiecych, przeznaczające część swej produkcji zbożowej na sprzedaż. W przypadku areału przekraczającego 0,5 łanu wymagałyby one prawdopodobnie dodatkowej siły roboczej;

- gospodarstwa o areale 1,00 łanu i większe - odpowiadające rozmiarami dużym gospodarstwom kmiecym lub małym folwarkom drobnej szlachty posiadającej kmieci, których funkcjonowanie wymagałoby obecności stałego personelu najemnego.

W przypadku drobnej szlachty posiadającej kmieci jej majątki można analizować w przedziałach jednołanowych. Majątki posiadajace maksymalnie 1 łan kmiecy byłyby traktowane jako odpowiadające folwarkom o areale uprawnym 1,5-2,0 łanów. Wzrost będącego w dyspozycji

12 A. Wyczański, Studia nad folwarkiem szlacheckim w Polsce w latach 1500-1580, Warszawa 1960; M. Kamler, Folwark szlachecki w Wielkopolsce w latach 1580-1655, Warszawa 1976.

${ }_{13} \mathrm{P}$. Guzowski, Chtopi i pieniadze na przełomie średniowiecza i czasów nowożytnych, Kraków 2008, s. 108-135; tenże, Wyznaczniki biedy w społeczności chłopskiej $w$ poczatkach epoki nowożytnej, w: Bieda $w$ Polsce, red. G. Miernik, Kielce 2012, s. $35-45$. 
majątku szlacheckiego areału kmiecego o każdy kolejny łan odpowiadałby dla końca XVI w. każdorazowo w przybliżeniu zwiększeniu areału folwarcznego o 0,50 łanu $^{14}$.

Dane dotyczące liczby majątków szlacheckich, ich wielkości oraz nasycenia zagrodnikami będą pochodzić z rejestrów poboru ziemskiego województw płockiego z 1578 r., łęczyckiego z 1580 r., kaliskiego z lat 1580 i 1581, poznańskiego z lat 1580-1582 i krakowskiego z 1581 r. $^{15}$ Dobór wykorzystanych rejestrów wynikał z ich dostępności w formie pozwalającej na przeprowadzenie rekonstrukcji majątków szlacheckich. W przypadku województw płockiego, łęczyckiego i krakowskiego dysponowałem rejestrami wcześniej opracowanymi przeze mnie na potrzeby innej publikacji. Natomiast rejestry województw poznańskiego i kaliskiego, dzięki ich opublikowaniu w formie cyfrowej przez Zakład Atlasu Historycznego IH PAN, pozwalały na wykonanie takiej właśnie operacji. Mimo znacznej przewagi danych odnoszacych się do Wielkopolski, wykorzystane rejestry obejmuja tereny bardzo się od siebie różniące pod względem zlokalizowania $\mathrm{w}$ obrębie ówczesnej przestrzeni gospodarczej. Trzy spośród analizowanych województw były w całości lub częściowo zaangażowane w spław płodów rolnych do Gdańska. Województwo płockie, reprezentujące Mazowsze, położone było relatywnie blisko tego miasta portowego i znajdowało się w strefie jego oddziaływania gospodarczego już od połowy XV w. ${ }^{16}$ Województwo łęczyckie, wobec braku bezpośredniego dostępu do Wisły, znalazło się w tej samej strefie dość późno, bo dopiero około połowy XVI w. ${ }^{17} \mathrm{~W}$ przypadku województwa kaliskiego jego północna część w XVI stuleciu brała udział w spławie zboża do Gdańska, natomiast południowa znajdowała się w zasięgu

${ }^{14}$ A. Wyczański, Studia nad folwarkiem..., s. 72-74. Areał 1,5-2,0 łanów pozwalałby na zaspokojenie potrzeb biologicznych rodziny szlacheckiej i sfinansowanie podstawowych wydatków koniecznych dla manifestowania jej szlacheckiego statusu. Założenie wzrostu areału folwarcznego o 0,50 łanu wraz z powiększeniem areału kmiecego o 1 łan wynika z założenia, że pańszczyzna z 1 łanu kmiecego umożliwiała w owym okresie kompleksową uprawę maksymalnie 0,50 łanu folwarcznego.

${ }_{15}$ Dane dla woj. krakowskiego, łęczyckiego i płockiego zostały zaczerpnięte z: K. Boroda, Geografia gospodarcza Królestwa Polskiego w XVI wieku, Białystok 2016. Dane dla woj. poznańskiego i kaliskiego zostały opracowane na podstawie podstawowych rejestrów podatkowych, opublikowanych w formie elektronicznej: Atlas źródet $i$ materiatów do dziejów dawnej Polski, 2015, nr 2 i 3, http://atlasfontium.pl/index. php?article=kaliskie; http://atlasfontium.pl/index.php?article=poznanskie (5 V 2017).

${ }^{16} \mathrm{M}$. Biskup, Z problematyki handlu polsko-gdańskiego drugiej połowy XV wieku, PH, t. 45, 1954, z. 2-3, s. 394.

${ }_{17}$ B. Baranowski, Rozwój gospodarki folwarczno-pańszczyźnianej w województwie tęczyckim i wschodniej części województwa sieradzkiego do połowy XVII wieku, „Zeszyty Naukowe Uniwersytetu Łódzkiego”, seria 1, 1955, z. 1, s. 82-85. 
gospodarczego oddziaływania Wrocławia ${ }^{18}$. Dwa pozostałe województwa - poznańskie i krakowskie - nie były zwiąane w XVI w. z gdańskim rynkiem zbożowym. W przypadku poznańskiego jego produkcja rolna nakierowana była przede wszystkim na spław Wartą w kierunku Szczecina, wywóz lądem na Śląsk oraz na zaspokajanie potrzeb konsumpcyjnych Poznania, będącego w tym czasie istotnym centrum produkcji rzemieślniczej i ważnym węzłem komunikacyjnym w lądowym obrocie towarowym ${ }^{19}$. Aktywność gospodarczą województwa krakowskiego w tym zakresie warunkowało istnienie aglomeracji krakowskiej, będącej bardzo dużym centrum produkcji rzemieślniczej, niezwykle ważnym węzłem komunikacyjnym z krzyżującymi się lądowymi szlakami handlowymi prowadzącymi z Węgier w stronę Gdańska oraz z ziem ruskich i Mołdawii na Śląsk, a także centrum rezydencjonalnym królów polskich ${ }^{20}$. Przygotowywana przez Zakład Atlasu Historycznego IH PAN dla całego obszaru Wielkopolski, Małopolski, Mazowsza, Prus Królewskich oraz Podlasia edycja podstawowych rejestrów poborowych z przełomu lat 70 . i 80. XVI stulecia pozwoli w przyszłości uzupełnić i zweryfikować ustalenia poczynione w poniższym artykule.

\section{Drobna szlachta w strukturze majątkowej szlachty posiadającej kmieci}

We wszystkich analizowanych województwach drobna szlachta, a więc posiadacze maksymalnie 5 łanów kmiecych, stanowiła zbiorowość dominującą pod względem liczbowym wśród szlachty posiadającej kmieci. Skala tej dominacji była jednak bardzo różna, gdyż w województwie krakowskim obejmowała ona 57\% zrekonstruowanych majątków szlacheckich, w poznańskim 68\%, w kaliskim 74\%, w łęczyckim 80\%, a w płockim $85 \%$ (zob. wykres 1 ). W przypadku dwóch ostatnich województw kluczowym czynnikiem stojącym za niezwykle wysokim udziałem drobnej szlachty w strukturze majątkowej stanu szlacheckiego jest wyjątkowa liczna obecność majątków posiadających w swej dyspozycji

18 S. Mielczarski, Rynek zbożowy na ziemiach polskich $w$ drugiej połowie XVI i pierwszej połowie XVII wieku. Próby rejonizacji, Gdańsk 1963.

${ }^{19} \mathrm{~K}$. Chojnacka, Handel na Warcie $i$ Odrze $w$ XVI i pierwszej połowie XVII wieku, Poznań 2007.

${ }^{20}$ J.M. Małecki, Studia nad rynkiem regionalnym Krakowa $w$ XVI wieku, Warszawa 1963; H. Obuchowska-Pysiowa, Udziat Krakowa $w$ handlu zagranicznym Rzeczypospolitej w pierwszych latach XVII wieku, Wrocław 1981; R. Rybarski, Handel i polityka handlowa Polski w XVI stuleciu, t. 1: Rozwój handlu i polityki handlowej, Warszawa 1928. 
Wykres 1. Struktura majątkowa szlachty posiadającej kmieci w województwach poznańskim, kaliskim, krakowskim, łęczyckim i płockim w latach 1578-1582. Majątki rekonstruowane

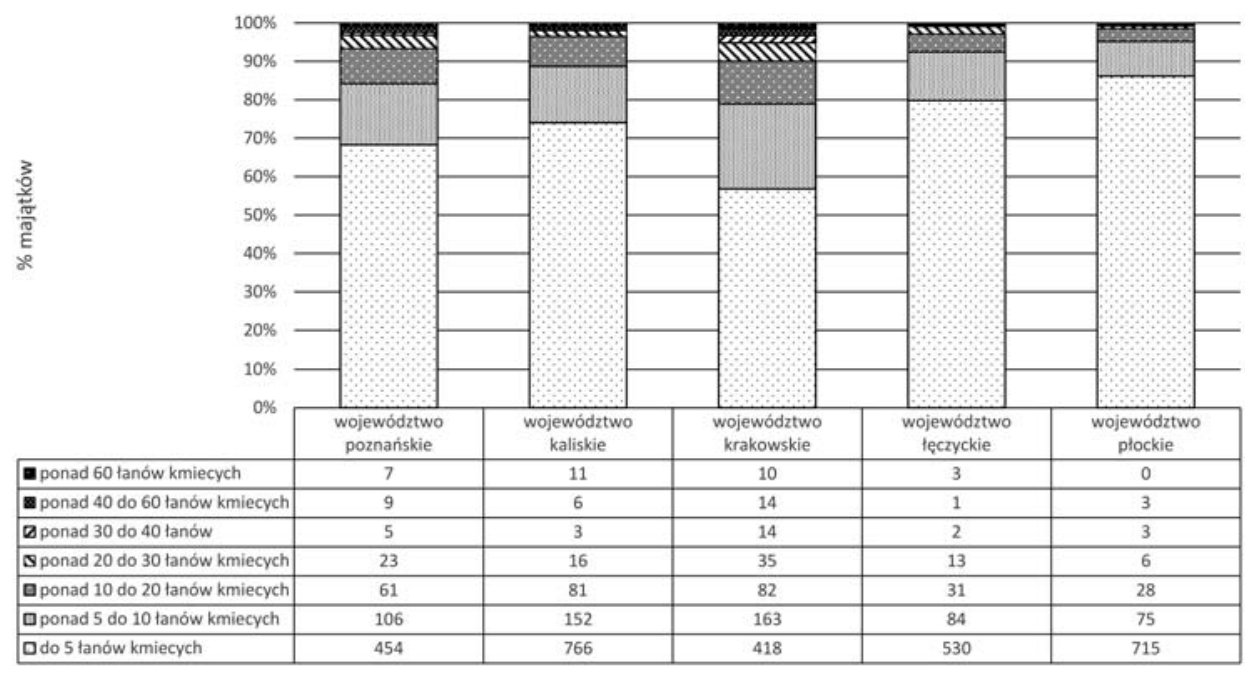

nie więcej niż 1 łan kmiecy, a więc należących do szlachty określanej dotąd w literaturze przedmiotu, z racji posiadania jedynie fragmentu wsi, jako czasstkowa. O ile bowiem w województwie poznańskim majątki o tym rozmiarze stanowiły jedynie $6 \%$, w krakowskim 16\%, a w kaliskim 24\% wszystkich zrekonstruowanych, to w płockim było to $45 \%$, a w łęczyckim $42 \%$.

Mierzac gospodarcze znaczenie szlachty drobnej jej udziałem w opodatkowanym areale kmiecym, wypada zauważyć, że w województwie krakowskim było ono niewielkie. W jej dyspozycji znajdowało się tam jedynie $15 \%$ areału kmiecego będącego w posiadaniu szlachty. Nieco większy był jej udział w województwie poznańskim - 23\% i kaliskim - 28\%. Za to w województwach łęczyckim i płockim udział drobnej szlachty w areale kmiecym na poziomie odpowiednio 33 i 43\% czynił z niej potencjalnie bardzo istotny - a dla województwa płockiego wręcz kluczowy - element lokalnych realiów gospodarczych schyłku XVI w. (zob. wykres 2).

\section{Szlachta bezkmieca}

W przypadku szlachty bezkmiecej, odmiennie niż w przypadku szlachty posiadajacej kmieci, mamy do czynienia z olbrzymia dysproporcją w zakresie liczby rekonstruowanych dla poszczególnych województw majątków. Łączna liczba majątków szlachty bezkmiecej 
Wykres 2. Udział w areale kmiecym poszczególnych kategorii szlachty posiadającej kmieci w opodatkowanym przez nia areale kmiecym w województwach poznańskim, kaliskim, krakowskim, łęczyckim i płockim w latach 1578-1582

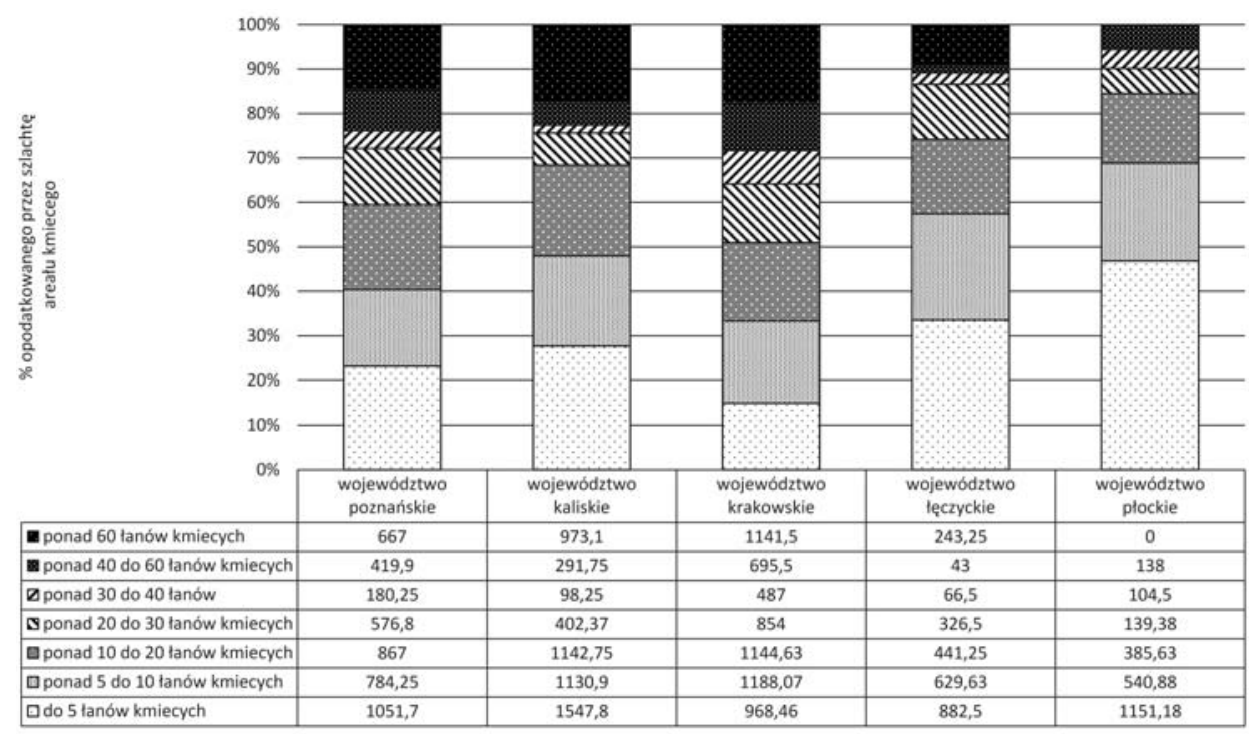

zrekonstruowanych dla województwa krakowskiego wynosi bowiem 228, dla kaliskiego 348, dla łęczyckiego 951, dla płockiego aż 3470, podczas gdy w województwie poznańskim są to jedynie 3 majątki (zob. wykres 3).

W województwie poznańskim zupełnie marginalnej ich obecności towarzyszą relatywnie duże rozmiary gospodarstw, gdyż we wszystkich przypadkach opłacony został podatek od areału znacznie większego niż 1 łan $^{21}$. Województwo krakowskie charakteryzuje się natomiast niemal zupełnym brakiem majątków mniejszych niż 0,25 łanu, podczas gdy w województwie kaliskim stanowią one 10\% ogólnej liczby, a w łęczyckim i płockim po niemal 20\%. Najliczniej w przypadku tych czterech województw reprezentowane sa gospodarstwa mieszczące się w przedziale od 0,25 do 0,99 łanu, stanowiące każdorazowo od 50 do $65 \%$ majątków bezkmiecych. Majątki duże, o rozmiarach zbliżonych do małych folwarków szlachty posiadajacej kmieci, stanowiły od 40\% w województwach krakowskim i kaliskim, poprzez 25\% w łęczyckim, po jedynie około $18 \% \mathrm{w}$ płockim.

Analiza potencjału gospodarczego trzech wyodrębnionych, szerokich kategorii majątkowych wskazuje, że w województwach krakowskim,

${ }^{21}$ Było to łącznie 6,5 łanu. Poza tym zarejestrowane zostało jeszcze 14 łanów $\mathrm{w}$ uprawie własnej, jednak nie jako majątki bezkmiece, lecz jako dzierżawione przez szlachtę posiadającą kmieci części składowe ich majątków. 
Wykres 3. Struktura majątkowa szlachty bezkmiecej województw poznańskiego, kaliskiego, krakowskiego, łęczyckiego i płockiego w latach 1578-1582. Majątki rekonstruowane

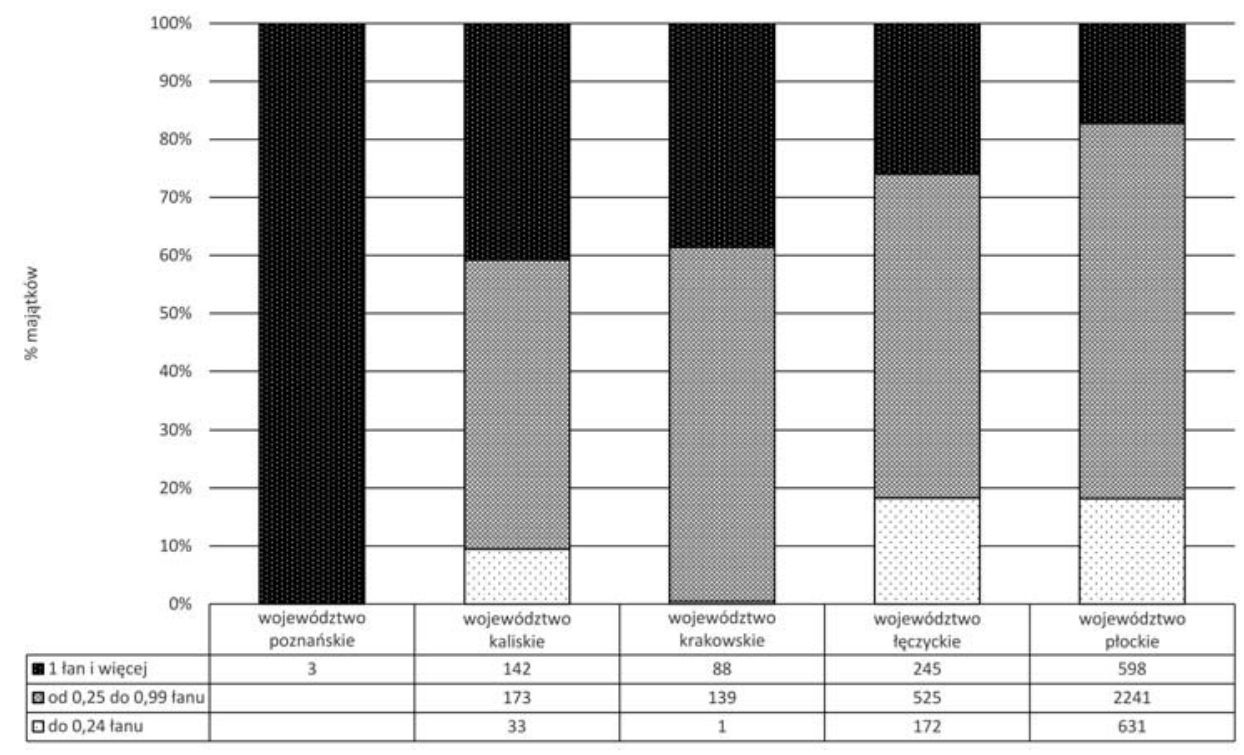

kaliskim i łęczyckim dominowały majątki duże, o areale 1 łanu lub większym, skupiające 60-70\% ziemi zgłoszonej do opodatkowania, a w przypadku województwa poznańskiego jednostek gospodarczych mniejszych niż 1 łan nie było w ogóle. W województwie płockim natomiast przeważały gospodarstwa zbliżone rozmiarami do gospodarstw kmiecych, obejmujace około 55\% opodatkowanego areału. Majątki najmniejsze, o opodatkowanym areale nieprzekraczajacym 0,25 łanu, mimo występowania w znacznej liczbie w województwach łęczyckim i płockim, miały marginalne znaczenie, obejmując jedynie 3-4\% opodatkowanej ziemi.

Trzeba w tym miejscu jednak zastrzec, że o ile rekonstrukcja majątków przeprowadzona dla województw krakowskiego, poznańskiego, kaliskiego i łęczyckiego nie budzi większych zastrzeżeń, o tyle w przypadku województwa płockiego jej wiarygodność, zwłaszcza w odniesieniu do szlachty bezkmiecej, nie jest pewna. W zachowanych dla tego województwa rejestrach poborowych, poza pojawiającymi się wszędzie przypadkami braku rejestracji danych personalnych płatników podatku, występuje dodatkowo praktyka nieuaktualniania (w skrajnych przypadkach nawet na przestrzeni kilkudziesięciu lat) wykazywanych w nich płatników podatku ${ }^{22}$.

${ }^{22}$ I. Gieysztorowa, Źródła i szacunki w badaniach osadnictwa i demografii Polski XVI i XVII w., KHKM, t. 10, 1962, nr 3-4, s. 581. 
Wykres 4. Porównanie potencjału gospodarczego szlachty bezkmiecej województw poznańskiego, kaliskiego, krakowskiego, łęczyckiego i płockiego w latach 1578-1582. Majątki rekonstruowane

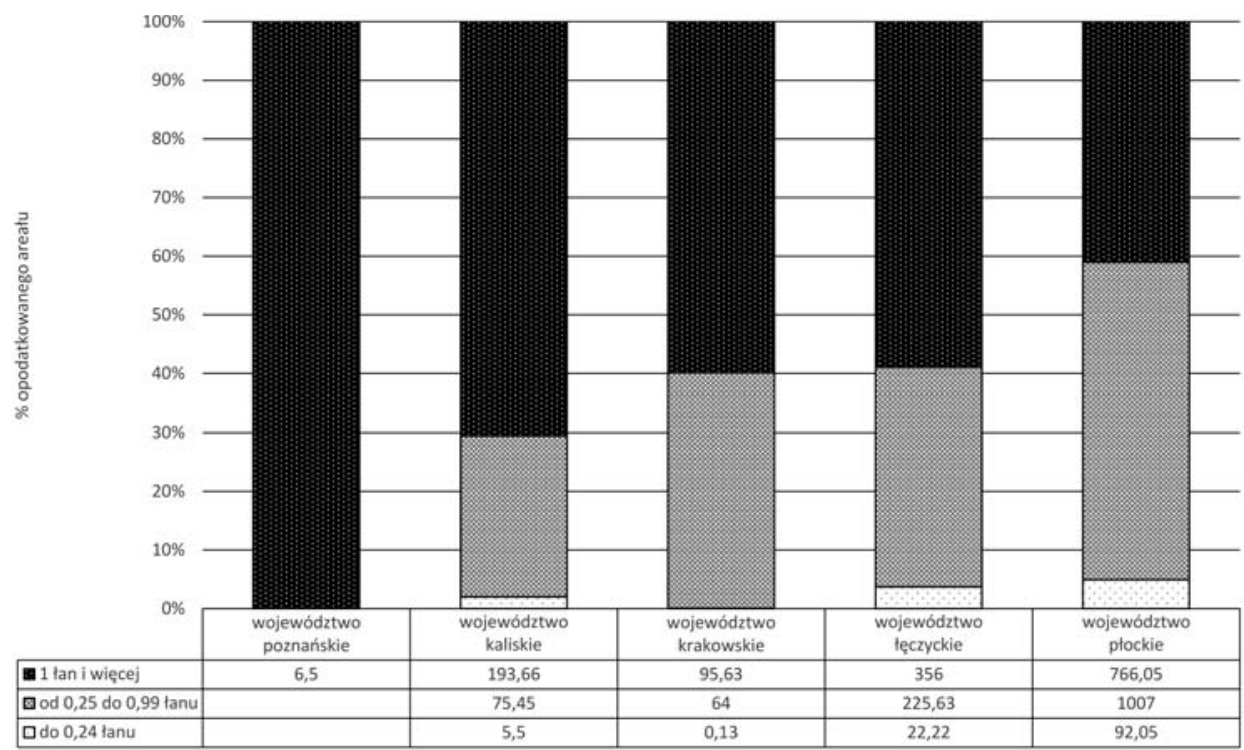

\section{Nasycenie zagrodnikami majątków drobnej szlachty posiadającej kmieci}

Do sprawnego funkcjonowania dochodowego folwarku konieczne było zapewnienie mu odpowiedniego zasobu siły roboczej. W przypadku terenów będących bezpośrednim zapleczem portów bioracych udział w eksporcie zboża czy też dużych ośrodków miejskich możliwe było oparcie pracy folwarku w głównej mierze na pracy najemnej ${ }^{23}$. Jednak w miarę oddalania się od nich utrzymanie opłacalności produkcji folwarcznej wymagało sięgania po niegenerującą kosztów finansowych pańszczyznę. Zapotrzebowanie na pracę w obrębie folwarku istniało przez cały rok, ale jego największe spiętrzenie następowało przede wszystkim w okresie orki, siewów, żniw i omłotów, angażując różne typy pańszczyzny. W trakcie orki i częściowo siewów kluczową rolę odgrywała pańszczyzna sprzężajna, a w okresie żniw i omłotów - pańszczyzna piesza. Głównymi dostarczycielami tej ostatniej byli zagrodnicy, a jej wymiar w drugiej połowie XVI w. wynosił zwykle 3 dni w tygodniu z gospodarstwa

${ }^{23}$ A. Mączak, Struktura majatkowa szlachty pomorskiej $w$ XVI-XVII w. Próba analizy statystycznej, PH, t. 53, 1962, z. 4, s. 645-671; J. Majewski, Gospodarstwo folwarczne we wsiach miasta Poznania w latach 1582-1644, Poznań 1957. 
zagrodniczego ${ }^{24}$. Obok nich istotną rolę w tym zakresie odgrywali także kmiecie, którzy w miejsce 1 dniówki pańszczyzny sprzężajnej byli obowiązani do świadczenia 2 dniówek pańszczyzny pieszej. Jednak przy średnim wymiarze pańszczyzny sprzężajnej 3 dni z łanu w tygodniu półłanowe gospodarstwo kmiece o areale 15 mórg dostarczało tygodniowo tyle samo pańszczyzny pieszej ( $3 \mathrm{dni}$ ) co gospodarstwo zagrodnicze o areale 3-6 mórg.

Kalkulacje zapotrzebowania na pracę w okresie żniw i omłotów, wykonane przez Andrzeja Wyczańskiego dla przeciętnego folwarku o areale 3,5-4,0 łanów, $\mathrm{w}$ połączeniu $\mathrm{z}$ danymi na temat relacji między liczbą łanów folwarcznych a kmiecych w majątku, pozwalają na wyliczenie średniego nasycenia zagrodnikami na łan kmiecy niezbędnego do pełnej realizacji zapotrzebowania na pracę w okresie omłotów i żniw w przeciętnym folwarku ${ }^{25}$. Zabezpieczenie zasobu siły roboczej niezbędnej do przeprowadzenia omłotów - bez konieczności zatrudniania pracowników najemnych - wymagałoby nasycenia w drugiej połowie XVI w. przeciętnego folwarku zagrodnikami na poziomie $0,6-0,7$ osoby na 1 łan kmiecy. Do pełnego zabezpieczenia zapotrzebowania w okresie żniw, zależnie od regionu kraju, konieczne byłoby natomiast nasycenie na poziomie 2,5-4,5 zagrodników na 1 łan kmiecy. W przypadku małego folwarku drobnoszlacheckiego, o areale uprawnym 1,5-2,0 łanów - przy założeniu dysponowania przez jego właściciela 1 łanem kmiecym - wyliczenie niezbędnego nasycenia zagrodnikami prowadzi do wniosku, że do pełnego zabezpieczenia zapotrzebowania na pracę w okresie omłotów konieczne było nasycenie nimi na poziomie $0,6-0,7$ osoby na 1 łan kmiecy. Byłby to więc poziom identyczny jak w przypadku folwarku o areale 3,5-4,0 łanu. Jednak do pełnego zabezpieczenia zapotrzebowania na pracę w okresie żniw konieczna byłaby w małych folwarkach drobnej szlachty znacznie wyższa obecność zagrodników, na poziomie 4,0-6,0 osób na 1 łan kmiecy ${ }^{26}$.

Wyliczenie dla analizowanych województw nasycenia zagrodnikami majątków rekonstruowanych szlachty posiadającej kmieci wskazuje wyraźnie, że majątki drobnej szlachty (posiadaczy maksymalnie 5 łanów kmiecych) charakteryzowały się wszędzie wyjątkowo wysokim (o 50-100\% wyższym niż kolejna kategoria majątkowa) nasyceniem zagrodnikami (zob. wykres 5).

\footnotetext{
${ }^{24}$ A. Wyczański, Studia nad folwarkiem..., s. 121-122.

25 Tamże, s. 131-138.

${ }^{26}$ K. Boroda, Geografia gospodarcza Królestwa Polskiego..., s. 259-273.
} 
Wykres 5. Nasycenie zagrodnikami majątków szlachty posiadającej kmieci w województwach poznańskim, kaliskim, krakowskim, łęczyckim i płockim w latach 1578-1582. Majątki rekonstruowane

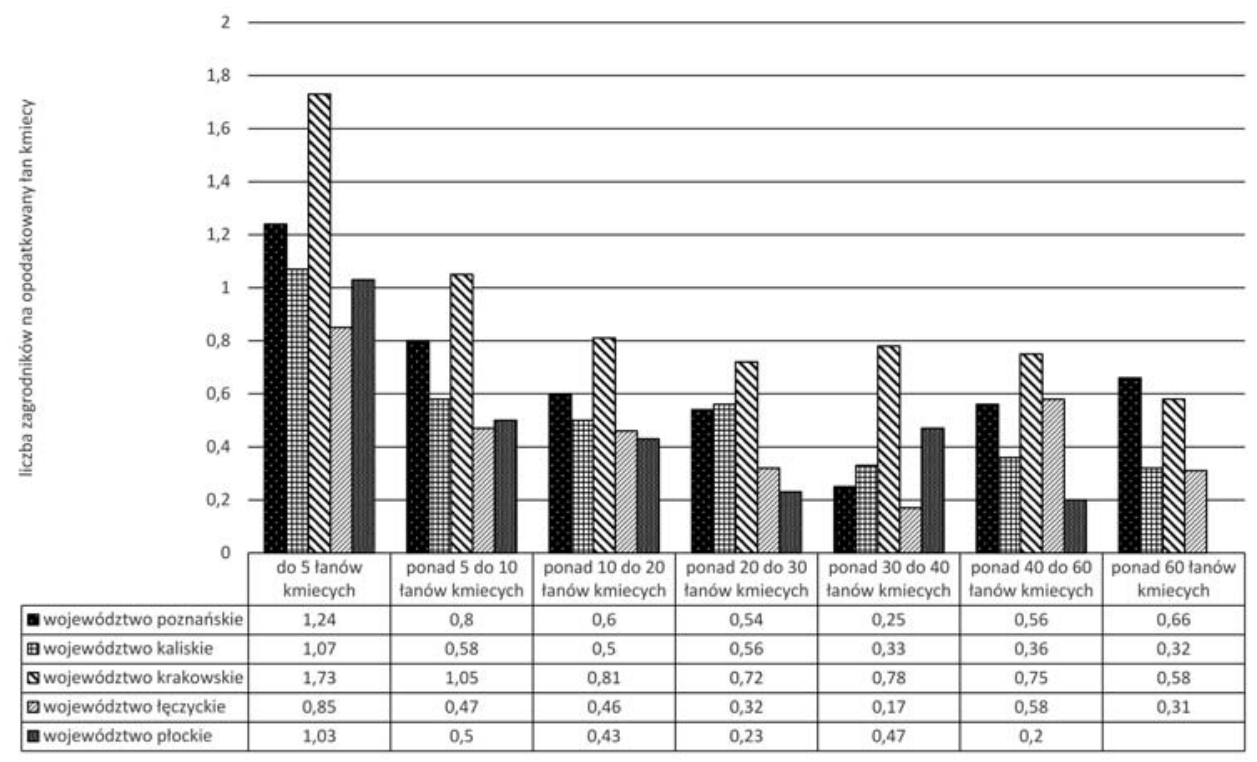

Zauważalna jest przy tym wyjątkowość województwa krakowskiego, gdzie nasycenie zagrodnikami niemal we wszystkich kategoriach majątkowych jest wyraźnie wyższe niż w pozostałych województwach. Jeśli strukturę majątkową drobnej szlachty (posiadaczy do 5 łanów kmiecych) rozbijemy na przedziały jednołanowe, widoczna staje się tendencja do wzrostu nasycenia zagrodnikami w miarę spadku rozmiarów areału kmiecego pozostającego w dyspozycji gospodarstwa szlacheckiego (zob. wykres 6).

W przypadku wszystkich województw poza krakowskim dla majątków dysponujacych 5 łanami kmiecymi, a więc odpowiadajacych majątkowi o przeciętnym folwarku o areale 3,5-4,0 łanów, nasycenie zagrodnikami kształtuje się na poziomie zbliżonym do koniecznego, by zbilansować zapotrzebowanie na pracę w okresie omłotów. Natomiast w majątkach dysponujących maksymalnie 1 łanem kmiecym, a więc odpowiadających folwarkom o hipotetycznym areale 1,5-2,0 łanów, nasycenie zagrodnikami sugeruje istnienie w nich dużych nadwyżek podaży pańszczyzny pieszej w okresie omłotów i silnie zredukowany, zwłaszcza w województwie poznańskim, deficyt dniówek pańszczyźnianych w okresie żniw. W województwie krakowskim zaś nawet majątki dysponujące 5 łanami kmiecymi wykazują poważne nadwyżki podaży pańszczyzny w okresie 
Wykres 6. Nasycenie zagrodnikami majątków drobnej szlachty posiadającej kmieci w województwach poznańskim, kaliskim, krakowskim, łęczyckim i płockim w latach 1578-1582. Majątki rekonstruowane

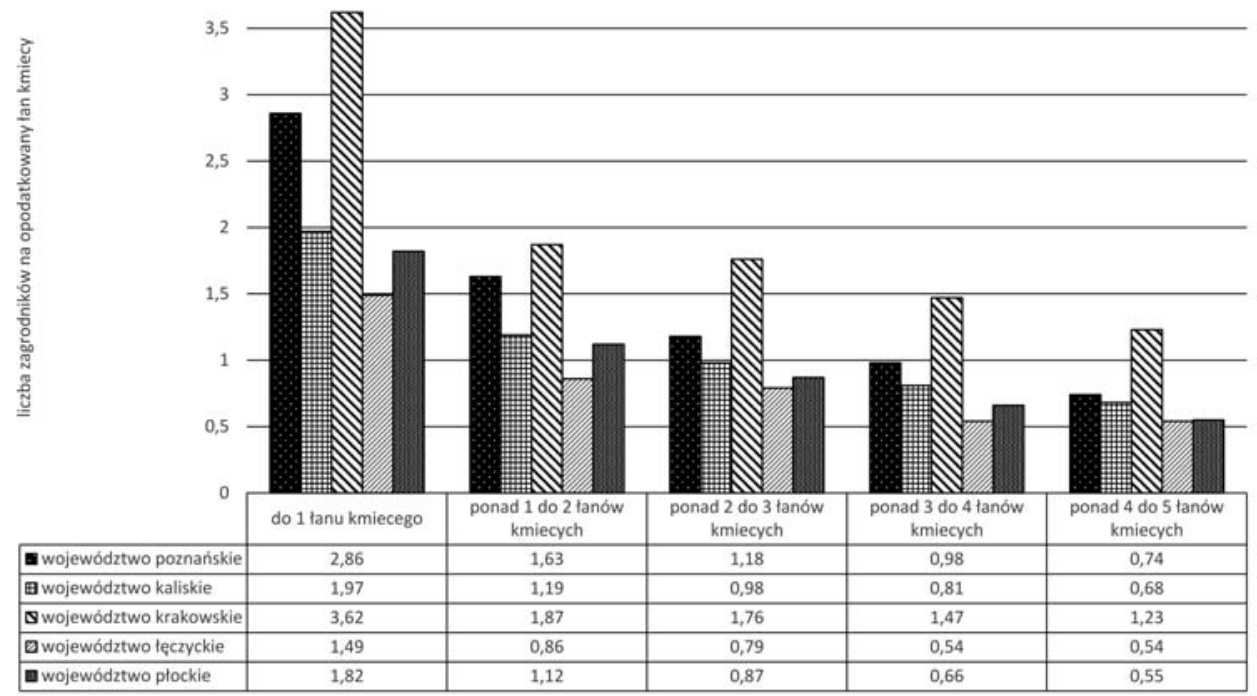

omłotów, a dysponujące nie więcej niż 1 łanem kmiecym pod względem nasycenia zagrodnikami zbliżają się do poziomu zapewniającego zbilansowanie zapotrzebowania na pracę w okresie żniw.

\section{Nasycenie zagrodnikami majątków szlachty bezkmiecej}

W przypadku szlachty nieposiadajacej kmieci analiza obecności zagrodników wymaga, poza odniesieniem się do danych o wielkości rekonstruowanych majątków, także uwzględnienia wielkości zgłaszanych działów podatkowych. Dość często mamy bowiem do czynienia z praktyka sumowania ze sobą wpłat od kilku podatników pochodzących z jednej miejscowości. Rekonstrukcja majatków wymagała w tej sytuacji dzielenia podstawy podatkowej między wszystkich wymienionych właścicieli. Tymczasem działy takie mogły stanowić jednorodne jednostki gospodarcze, w obrębie których jako całości odbywała się ewentualna kalkulacja zapotrzebowania na siłę roboczą lub też wykazywani w nich zagrodnicy mogli przynależeć tylko do jednego spośród wymienionych właścicieli. Zarazem, inaczej niż w przypadku 
Wykres 7. Odsetek majątków rekonstruowanych szlachty bezkmiecej wykazujących obecność zagrodników w województwach poznańskim, kaliskim, krakowskim, łęczyckim i płockim w latach 1578-1581

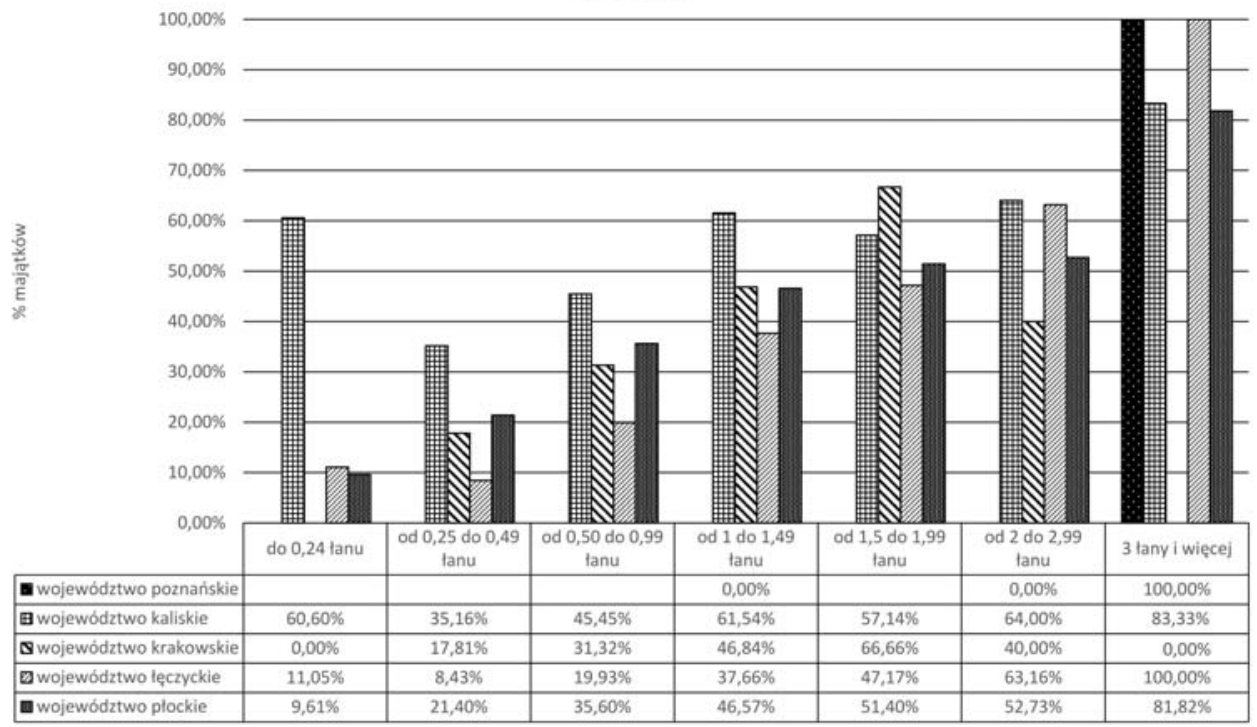

Wykres 8. Odsetek działów podatkowych szlachty bezkmiecej wykazujących obecność zagrodników w województwach poznańskim, kaliskim, krakowskim, łęczyckim i płockim w latach 1578-1582

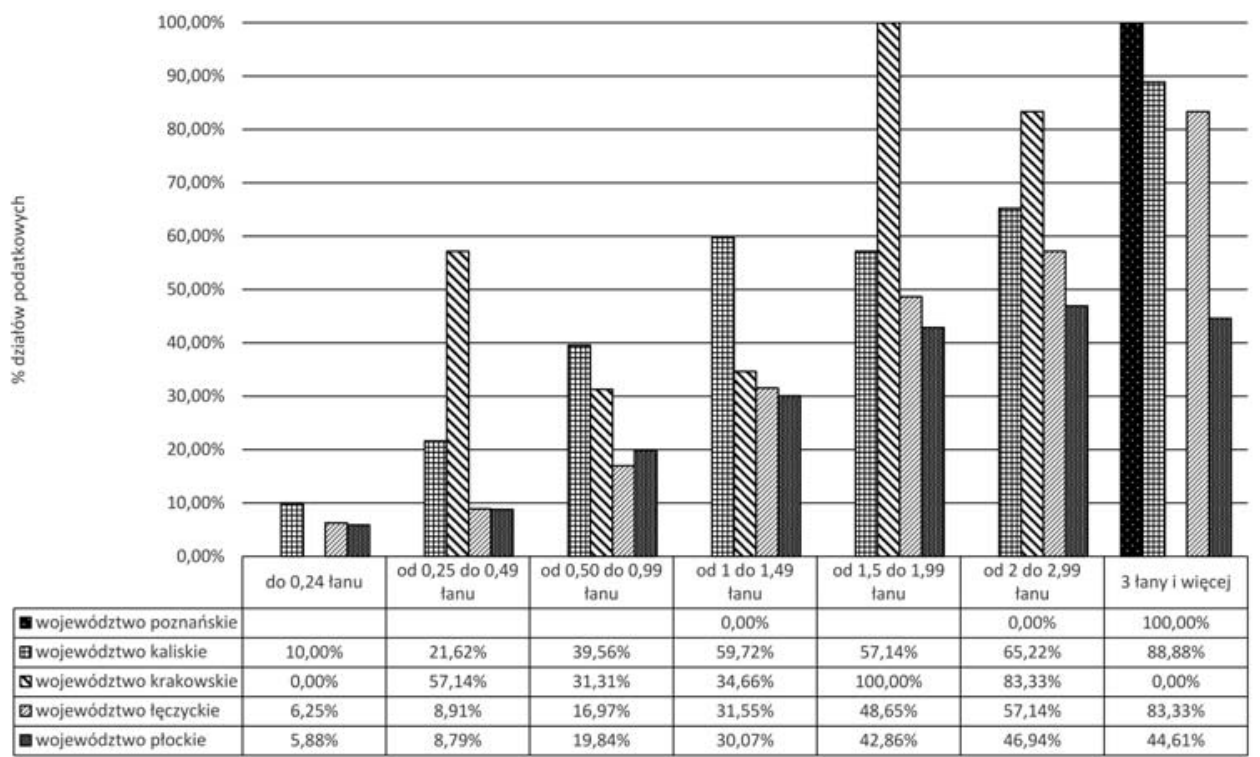


szlachty posiadającej kmieci, analizowane będzie nie średnie nasycenie zagrodnikami na opodatkowany łan, ale odsetek zrekonstruowanych gospodarstw i działów podatkowych wykazujących obecność zagrodników .

Wykresy 7 i 8 wskazują na istnienie wyraźnej tendencji do zwiększania się - w miarę wzrostu rozmiarów zarówno majątków rekonstruowanych, jak i zgłaszanych do opodatkowania działów - odsetka jednostek gospodarczych wykazujących obecność zagrodników. Jednak o rzeczywistej obecności zagrodników możemy mówić dopiero w przypadku jednostek gospodarczych o areale 0,5 łanu lub większym. W majątkach rekonstruowanych o wielkości do 0,24 łanu wszystkie przypadki zarejestrowania ich obecności dotycza sytuacji, gdy w ramach operacji rekonstruowania majątków większe działy podatkowe zostały podzielone między przypisanych do nich podatników. W działach podatkowych o tym rozmiarze pojawiają się oni natomiast jedynie wówczas, gdy sa one częścią większego kompleksu majątkowego tworzonego przez dwa lub więcej działów pozostających w posiadaniu jednej osoby. To samo dotyczy też większości zarówno majątków, jak i działów podatkowych o wielkości 0,25-0,49 łanu. Dopiero począwszy od jednostek o areale 0,5 łanu możemy mówić o zauważalnej obecności zagrodników, pojawiających się w 20-30\% z nich. W jednostkach o wielkości co najmniej 1 łanu sa oni obecni w 30-40\%, a przy wielkości 1,5 łanu ich obecność możemy stwierdzić w około 50\% jednostek. Granica 0,5 łanu, od której zaczynali się pojawiać zagrodnicy, odpowiada zasadniczo ustaleniom $\mathrm{w}$ zakresie zapotrzebowania na dodatkowe ręce do pracy w przypadku gospodarstw kmiecych. Areał 0,5 łanu był bowiem maksymalnym możliwym do uprawy przy wykorzystaniu wyłącznie zasobów pracy rodziny chłopskiej, o ile nie uwzględnimy konieczności realizowania zobowiązań pańszczyźnianych. Stwierdzenie obecności zagrodników w około 20-30\% jednostek gospodarczych o wielkości 0,5-0,99 łanu i $30-40 \% \mathrm{w}$ przedziale 1,0-1,49 łanu nie oznacza jednak, że w pozostałych wykorzystywano wyłącznie zasoby pracy rodziny. Wykorzystywaną w niej opcja, rozmiarów której nie jesteśmy w stanie ocenić na podstawie źródeł skarbowych, było bowiem zatrudnianie stałej służby (parobków). Wzrost częstotliwości występowania zagrodników wydaje się być jednak swoistym sygnałem pojawiania się „folwarcznego" modelu organizacji pracy gospodarstw szlachty bezkmiecej, począwszy od areału 0,5 łanu. 


\section{Drobna szlachta w ogólnej strukturze stanu szlacheckiego}

Odrębne rozpatrywanie struktury majątkowej szlachty posiadajacej kmieci i bezkmiecej jest tradycyjnym zabiegiem badawczym praktykowanym w historiografii polskiej od czasów (jak już wspomniano) publikacji Adolfa Pawińskiego. Jednak z prawnego punktu widzenia szlachcic nieposiadający kmieci nie różnił się statusem prawnym od szlachcica posiadającego ich, podobnie jak nie było różnicy prawnej między posiadającym kmieci szlachcicem drobnym lub średniozamożnym a magnatem. Wszystkim im w teorii przysługiwały te same przywileje stanowe, ciążyły na nich te same obowiązi i wszyscy stawali przed obliczem tego samego sądu stanowego. Praktykowany na potrzeby badań podział na szlachtę „zagrodowa” i „folwarczną" nie jest efektem istnienia jakichś fundamentalnych różnic między członkami stanu szlacheckiego posiadającymi i nieposiadającymi poddanych kmieci, ale pochodna szesnastowiecznego systemu podatkowego i wytworzonych przez niego źródeł. W przypadku szlachty bezkmiecej - wobec właśnie braku kmieci - opodatkowaniu podlegała ziemia bezpośrednio użytkowana przez nia gospodarczo, a więc odpowiadająca swą funkcją nieopodatkowanym folwarkom szlachty posiadającej kmieci. Sam fakt osobistego opłacania podatku przez szlachtę bezkmieca nie wynikał z ich odmiennego statusu prawnego $\mathrm{w}$ porównaniu ze szlachta ich posiadająca, ale właśnie z jego identyczności. Na wszystkich członkach stanu szlacheckiego, jako bezpośrednich lennikach monarchy, ciążył bowiem obowiązek służenia mu rada i pomoca. Jedna $\mathrm{z}$ form realizowania tego obowiąków była służba wojskowa, w zastępstwie której mógł być nałożony podatek. Ponieważ przyjętym jeszcze w XV w. rozwiązaniem było uiszczanie tego podatku przez poddanych szlacheckich, dla szlachty nieposiadającej kmieci trzeba było przyjąć jakieś inne rozwiąanie, którym stało się opodatkowanie ziemi użytkowanej przez nią bezpośrednio. Jako że zazwyczaj była ona obciażana stawka podatkową odmienna niż gospodarstwa kmiece oraz z racji osobistego użytkowania ziemi bezpośrednim płatnikiem podatku był w tym wypadku szlachcic, a nie poddany mu kmieć. Wytworzył się więc w efekcie zwyczaj, nie do końca jednak powszechny, tworzenia odrębnych rejestrów podatkowych dla szlachty bezkmiecej ${ }^{27}$. Wobec istnienia odrębnych rejestrów niejako naturalnie $\mathrm{w}$ historiografii polskiej przyjęła się praktyka prowadzenia odrębnych

${ }^{27} \mathrm{~K}$. Boroda, O przydatności szesnastowiecznych rejestrów poborowych $w$ badaniach demograficznych, „Przeszłość Demograficzna Polski” 32, 2013, nr 2, s. 8. 
analiz struktury majątkowej szlachty posiadającej kmieci i nieposiadającej ich. Na brak uzasadnienia dla prowadzenia odrębnych analiz struktury majątkowej szlachty kmiecej i bezkmiecej uwagę zwracał już Antoni Mączak w swym artykule poświęconym strukturze majątkowej szlachty pomorskiej w XVI-XVII w. Sugerował on, by w przypadku tego regionu majątki szlachty bezkmiecej o areale do 3 łanów traktować jako rodzinne gospodarstwa szlacheckie, a o areale powyżej 3 łanów uznawać za folwark bezkmiecy, analizę zaś struktury majattkowej szlachty kmiecej i bezkmiecej prowadzić wspólnie, a nie oddzielnie ${ }^{28}$. Wyznaczenie granicy między szlacheckim gospodarstwem rodzinnym a folwarkiem bezkmiecym na poziomie 3 łanów motywował on przeciętną wielkościa gospodarstw gburskich na Pomorzu, które posiadały zwykle od 2 do 4 łanów ziemi. Można się domyślać, że było to pokłosie opinii Jana Rutkowskiego, który uważał, że za folwark można uznać jedynie takie gospodarstwo szlacheckie, które jest większe od największego gospodarstwa kmiecego w regionie ${ }^{29}$. Jednocześnie jednak analizy Antoniego Mączaka dotyczace sposobu funkcjonowania gospodarstw chłopskich na Żuławach w XVII w. wskazują wyraźnie, że mające od 2 do 4 łanów majątki gburskie gospodarczo były zorganizowane jak folwarki bezkmiece, a nie gospodarstwa rodzinne. Posiadały bowiem zwykle kilka osób stałej służby (parobków i dziewki), miewały własnych zagrodników, a w okresie żniw często korzystały z pracy najemnych pracowników sezonowych. Także rozmiary ich produkcji i kwoty osiaganych przychodów pieniężnych zbliżone były do tych notowanych w małych folwarkach ${ }^{30}$.

W tej sytuacji, kierując się kryteriami ekonomicznymi, można podzielić ogół szlachty na grupy majątkowe pozwalające na łączną analizę struktury majątkowej zarówno posiadających kmieci, jak i ich niemających ${ }^{31}$ :

- posiadaczy do 0,24 łanu w uprawie własnej (jednostki gospodarcze działające na zasadzie gospodarstw rodzinnych),

- posiadaczy od 0,25 do 0,99 łanu w uprawie własnej (jednostki gospodarcze o rozmiarach zbliżonych do gospodarstw kmiecych),

- posiadaczy nie więcej niż 1 łanu kmiecego, odpowiadającego posiadaniu folwarku o areale 1,5-2,0 łanów, lub co najmniej 1 łanu w uprawie własnej (jednostki gospodarcze wymagajace korzystania z najemnej siły roboczej i/lub pańszczyzny w celu zapewnienia prawidłowego funkcjonowania),

28 A. Mączak, Struktura majatkowa szlachty pomorskiej..., s. 646-647.

29 J. Rutkowski, Co to byty folwarki w dawnej Polsce, RDSG, t. 3, 1934, s. 119.

30 A. Mączak, Gospodarstwo chtopskie na Żuławach Malborskich w poczatkach XVII wieku, Warszawa 1962, s. 29-40, 162.

${ }^{31}$ Zob. K. Boroda, Geografia gospodarcza Królestwa Polskiego..., s. 247-256. 
- posiadaczy 2-5 łanów kmiecych, odpowiadajacych posiadaniu areału folwarcznego o maksymalnym rozmiarze przeciętnego folwarku (3,5-4,0 łany),

- posiadaczy 5-20 łanów kmiecych, odpowiadających posiadaniu areału folwarcznego większego niż jeden przeciętny folwark, ale nie większego niż cztery przeciętne folwarki,

- posiadaczy ponad 20 łanów, odpowiadające areałowi folwarcznemu przekraczajacemu cztery przeciętne folwarki.

Cała będąca przedmiotem naszego zainteresowania grupa drobnej szlachty znajdowałaby się w czterech przedziałach majątkowych obejmujacych gospodarstwa szlacheckie posiadające od mniej niż 0,25 łanu w uprawie własnej do 5 łanów kmiecych, odpowiadających maksymalnemu areałowi folwarcznemu 3,5-4,0 łanów. W jej skład wchodziłaby zatem cała szlachta określana tradycyjnie zagrodowa, znakomita większość szlachty nazywana cząstkową oraz część określanej jako jednowioskowa.

Zastosowanie takich zasad grupowania danych prowadzi do wniosku, że drobna szlachta dominowała liczebnie we wszystkich analizowanych województwach (zob. wykres 9). Jej udział w strukturze stanu szlacheckiego województwa krakowskiego wynosił 67\%, poznańskiego - 68\%, kaliskiego - 80\%, łęczyckiego - 92\%, a płockiego - 97\%. Przy czym w województwach krakowskim, kaliskim, a zwłaszcza poznańskim mamy w jej obrębie do czynienia $\mathrm{z}$ dominacją majątków zorganizowanych na zasadach funkcjonowania folwarków, a więc wykorzystujących pracę najemną i pańszczyznę. Szlacheckie gospodarstwa rodzinne, niekorzystające z pracy kmieci, stanowią w nich mniejszość, a w województwie poznańskim nie ma ich wcale. Także w województwie łęczyckim gospodarstwa $\mathrm{w}$ typie folwarcznych maja przewagę liczebna, podczas gdy w płockim zdecydowanie dominują majątki funkcjonujące najpewniej na zasadach gospodarstw rodzinnych.

Tak skonstruowane grupowanie, w przypadku chęci oceny potencjału gospodarczego poszczególnych kategorii majątkowych szlachty, wymaga sprowadzenia do wspólnego mianownika danych o liczbie tzw. łanów zagrodowych (ziemi znajdującej się w bezpośrednim użytkowaniu rodziny szlacheckiej) oraz łanów znajdujących się w użytkowaniu poddanych kmieci. By ocenić rzeczywiste znaczenie gospodarcze poszczególnych grup majątkowych szlachty, należy ocenić wielkość areału ziemi pozostającej w ich bezpośrednim użytkowaniu gospodarczym i będących podstawowym źródłem dochodów, a więc łanów tzw. zagrodowych i folwarcznych. Liczba łanów zagrodowych - wobec ich bezpośredniego opodatkowania - jest nam znana. Liczbę łanów folwarcznych, które nie 
Wykres 9. Porównanie struktury majątkowej szlachty województw poznańskiego, kaliskiego, krakowskiego, łęczyckiego i płockiego w latach 1578-1581. Majątki rekonstruowane

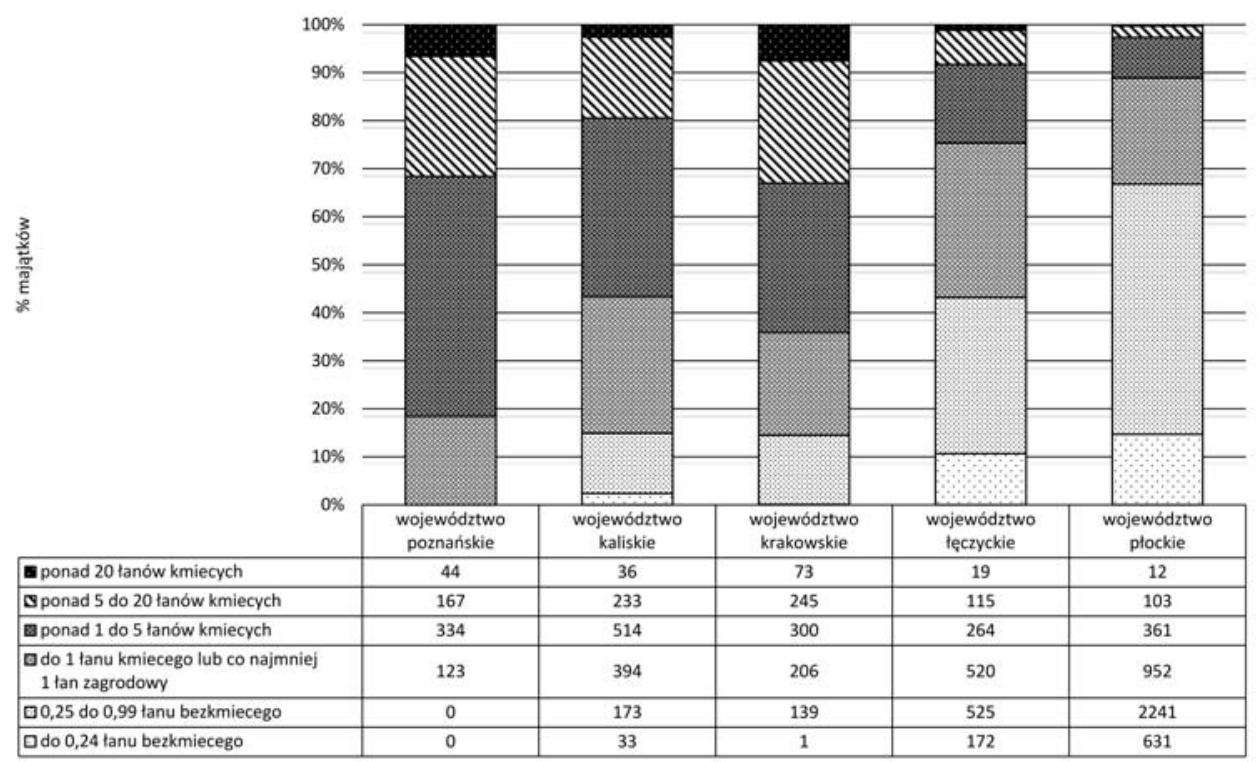

podlegały opodatkowaniu, trzeba oszacować na podstawie liczby łanów kmiecych. Problem stanowi konieczność różnicowania przeliczników relacji liczby łanów folwarcznych do kmiecych dla poszczególnych kategorii majatkowych szlachty folwarcznej. Dla drobnej szlachty (posiadaczy maksymalnie 5 łanów kmiecych) przyjęte zostało, że w majątkach o maksymalnie 1 łanie kmiecym areał folwarczny wynosił 2 łany niezależnie od regionu, a więc relacja liczby łanów folwarcznych do kmiecych wynosiłaby 2:1. Dla majątków dysponujących od 2 do 5 łanów kmiecych założony został wzrost areału folwarcznego o 0,5 łanu na każdy 1 łan kmiecy w kolejnych przedziałach jednołanowych. Relacja liczby łanów folwarcznych do kmiecych układałaby się wówczas następująco: do 2 łanów kmiecych - 1,25:1, do 3 łanów kmiecych - 1:1, do 4 łanów kmiecych $-1: 1,15$, do 5 łanów kmiecych $-1: 1,2$. Dla przedziału majątkowego 5-20 łanów kmiecych przyjęty został przelicznik 1:1,2. W odniesieniu do majątków większych niż 20 łanów kmiecych zastosowane zostały dwa przeliczniki: 1:1,5 dla majątków majacych 20-40 łanów i 1:2 dla majątków większych ${ }^{32}$. Przy czym oczywiście przyjęte przeliczniki

${ }^{32}$ Zwiększanie areału folwarcznego o 0,5 łanu wraz ze wzrostem areału kmiecego o 1 łan dla majątków o wielkości 2-5 łanów kmiecych wynika z założenia, że głównym 
Wykres 10. Porównanie potencjału folwarcznego ogółu szlachty województw poznańskiego, kaliskiego, krakowskiego, łęczyckiego i płockiego w latach 1578-1582

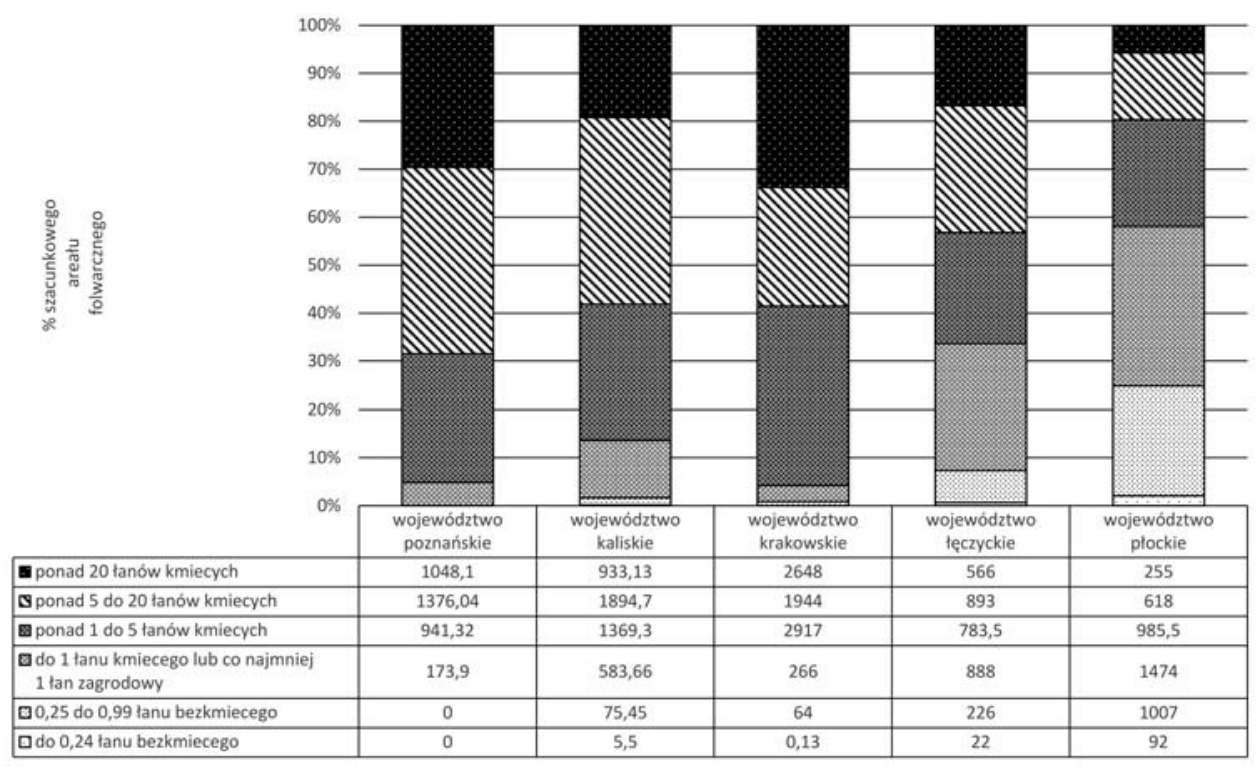

dają nam raczej obraz pewnych możliwości w zakresie wygenerowania areału folwarcznego niż sytuacji rzeczywistej.

Efekt szacunku prezentuje wykres 10 . Wskazuje on na silne zdominowanie pod względem gospodarczym społeczności szlacheckiej województwa płockiego przez drobną szlachtę, w której dyspozycji znajdowało się 80\% potencjału folwarcznego. Największa część tego potencjału zgromadzona była w niewielkich jednostkach gospodarczych o areale 1-2 łanów, w których produkcja zorganizowana była w głównej mierze na zasadach odpowiadajacych organizacji pracy folwarków. Jednocześnie istotne znaczenie odgrywała tu także dysponująca ponad $20 \%$

czynnikiem warunkującym zwiększenie rozmiarów folwarku była dostępność pańszczyzny sprzężajnej. Przelicznik dla majątków o wielkości 5-20 łanów kmiecych to efekt przyjęcia w tym zakresie ustaleń poczynionych przez Andrzeja Wyczańskiego i Marcina Kamlera. Przeliczniki dla majątków 20-40 łanów i ponad 40 łanów wynikają z założenia redukowania w nich intensywności prowadzonej gospodarki folwarcznej do poziomu, w którym uprawa gruntów folwarcznych byłaby oparta w całości (z wyłączeniu czasu żniw) na pańszczyźnie kmiecej. Ponadto badania dla dużej części Europy Środkowej i Wschodniej sugerują dużo niższe nasycenie majątków zamożniejszej szlachty łanami folwarcznymi niż w przypadku drobniejszej własności; zob. M. Cerman, Villagers and Lords in Eastern Europe, 1300-1800, Basingstoke-New York 2012, s. 61-70; szczegółowe omówienie wszystkich kryteriów zob. K. Boroda, Geografia gospodarcza Królestwa Polskiego..., s. 251-254. 
potencjału produkcyjnego grupa gospodarstw szlacheckich o rozmiarach zbliżonych do gospodarstw kmiecych, w których funkcjonował prawdopodobnie model pracy gospodarstw rodzinnych. Dla województwa łęczyckiego możemy mówić o przewadze, ale już nie dominacji, drobnej szlachty w zakresie zgromadzonego w jej dyspozycji potencjału folwarcznego. Największa jego część (choć w porównaniu do płockiego relatywnie mniejsza) zgromadzona była $\mathrm{w}$ gospodarstwach o rozmiarach 1-2 łanów, natomiast jednostki zorganizowane na zasadach gospodarstw rodzinnych odgrywały tutaj rolę marginalna. W województwach krakowskim, poznańskim i kaliskim w zakresie potencjału folwarcznego przeważa zaś większa własność, odpowiadająca posiadaczom areału folwarcznego przekraczajacego rozmiary przeciętnego folwarku. Drobna szlachta skupiała tu tylko 30-40\% potencjału folwarcznego, zlokalizowanego przede wszystkim w większych jednostkach gospodarczych o hipotetycznym areale 2,5-4,0 łanów, zorganizowanych na zasadach pracy właściwych dla folwarków.

\section{Podsumowanie}

Powyższe zestawienia dla pięciu województw (mimo pewnej nadreprezentacji terenów Wielkopolski) wskazuja, że w końcu XVI w. udział drobnej szlachty w strukturach stanu szlacheckiego był silnie zróżnicowany geograficznie. Przy czym we wszystkich analizowanych województwach przeważała ona liczbowo nad pozostałymi kategoriami społeczno-majątkowymi szlachty i to czasem, jak w województwie płockim, w sposób wręcz przytłaczający. Przekładało się to na lokalnie duże jej znaczenie gospodarcze, a - w przypadku regionów o dużej liczebności szlachty bezkmiecej - nawet na dominację w zakresie udziału w potencjale gospodarczym szlachty. Wydaje się przy tym, że istotne znaczenie miały tu lokalne uwarunkowania gospodarcze. Obecność dużych i aktywnych gospodarczo już w XV w. ośrodków miejskich jak Kraków czy Poznań stymulowała, jak się wydaje, proces komasowania majątków ziemskich na przyległych terenach. Natomiast tereny będące w zasięgu przeżywającego burzliwy rozkwit w XVI w. handlu zbożowego z Gdańskiem charakteryzowały się, jak się wydaje, warunkami sprzyjającymi utrzymywaniu się nawet bardzo drobnych majątków szlacheckich, w tym także szlacheckich gospodarstw rodzinnych niekorzystających - prawdopodobnie - z żadnej formy pańszczyzny (nie tylko sprzężajnej, ale także pieszej). W sferze organizacji życia gospodarczego drobnej szlachty widoczna jest silna tendencja do ograniczania kosztów finansowych 
działania prowadzonych przez nią jednostek gospodarczych, w których praca zorganizowana była na zasadach organizacji pracy folwarków kmiecych. Przejawem tego było dużo wyższe - w porównaniu do majątków zamożniejszej szlachty - nasycenie zagrodnikami majątków dysponujących maksymalnie 5 łanami kmiecymi, a zwłaszcza wyjątkowo wysokie nasycenie najmniejszych jednostek, dysponujących maksymalnie 1 łanem kmiecym. Jednocześnie obserwacja obecności zagrodników w szlacheckich gospodarstwach bezkmiecych wskazuje na korzystanie w ograniczonym zakresie z pańszczyzny pieszej, począwszy od jednostek o areale 0,5 łanu, a powszechniej 1 łanu.

\section{Bibliografia}

Atlas źródet i materiatów do dziejów dawnej Polski, 2015, nr 2 i 3, http://atlasfontium.pl/index.php?article=kaliskie; http://atlasfontium.pl/index.php?article=poznanskie (5 V 2017).

Baranowski B., Rozwój gospodarki folwarczno-pańszczyźnianej w województwie tęczyckim $i$ wschodniej części województwa sieradzkiego do połowy XVII wieku, „Zeszyty Naukowe Uniwersytetu Łódzkiego”, seria 1, 1955, z. 1, s. 81-103.

Biskup M., Z problematyki handlu polsko-gdańskiego drugiej potowy XV wieku, PH, t. 45,1954 , z. 2-3, s. 390-407.

Boroda K., Kmieć, tan czy profit? Co byto podstawa poboru tanowego w XV i XVI wieku?, w: Człowiek wobec miar i czasu w przeszłości, red. P. Guzowski, M. Liedke, Kraków 2007, s. 152-164.

Boroda K., O przydatności szesnastowiecznych rejestrów poborowych w badaniach demograficznych, „Przeszłość Demograficzna Polski” 32, 2013, nr 2, s. 21-38.

Boroda K., Geografia gospodarcza Królestwa Polskiego w XVI wieku, Białystok 2016.

Butkiewicz M., Dobra szlacheckie w powiecie tykocińskim, Lublin 1998.

Cerman M., Villagers and Lords in Eastern Europe, 1300-1800, Basingstoke-New York 2012.

Chojnacka K., Handel na Warcie i Odrze w XVI i pierwszej połowie XVII wieku, Poznań 2007.

Dworzaczek W., Skład społeczny wielkopolskiej reprezentacji sejmowej w latach 1572-1655, „Roczniki Historyczne” 23, 1957, s. 281-310.

Dworzaczek W., Leliwici Tarnowscy. Z dziejów możnowładztwa małopolskiego wiek XIV-XV, Warszawa 1971.

Gieysztorowa I., Źródła $i$ szacunki w badaniach osadnictwa $i$ demografii Polski XVI i XVII w., KHKM, t. 10, 1962, nr 3-4, s. 575-584.

Górczak Z., Rozwój majatków możnowładztwa wielkopolskiego $w$ drugiej połowie XV i poczatkach XVI wieku, Poznań 2007. 
Guldon Z., Rozmieszczenie własności ziemskiej na Kujawach w II połowie XVI w., Toruń 1964.

Guzowski P., Chłopi i pieniqdze na przełomie średniowiecza $i$ czasów nowożytnych, Kraków 2008.

Guzowski P., Wyznaczniki biedy w społeczności chłopskiej w poczatkach epoki nowożytnej, w: Bieda w Polsce, red. G. Miernik, Kielce 2012, s. 35-45.

Kamler M., Folwark szlachecki w Wielkopolsce w latach 1580-1655, Warszawa 1976.

Lubczyński M., Szlachta powiatu ksiaskiego za ostatnich Jagiellonów. Struktura majatkowa, Warszawa 2016.

Majewski J., Gospodarstwo folwarczne we wsiach miasta Poznania $w$ latach 1582-1644, Poznań 1957.

Malinowska J., Studia osadnicze na obszarze powiatu brzezińskiego do połowy XVI wieku, Toruń 2001.

Małecki J.M., Studia nad rynkiem regionalnym Krakowa w XVI wieku, Warszawa 1963.

Mączak A., Gospodarstwo chłopskie na Żuławach Malborskich w poczatkach XVII wieku, Warszawa 1962.

Mączak A., Struktura majątkowa szlachty pomorskiej w XVI-XVII w. Próba analizy statystycznej, PH, t. 53, 1962, z. 4, s. 645-671.

Mielczarski S., Rynek zbożowy na ziemiach polskich $w$ drugiej połowie XVI i pierwszej połowie XVII wieku. Próby rejonizacji, Gdańsk 1963.

Obuchowska-Pysiowa H., Udziat Krakowa w handlu zagranicznym Rzeczypospolitej w pierwszych latach XVII wieku, Wrocław 1981.

Polaszewski L., Własność feudalna w województwie kaliskim w XVI wieku, Poznań 1976.

Polska XVI wieku pod względem geograficzno-statystycznym, oprac. A. Pawiński, t. 1: Wielkopolska, Warszawa 1883 (Źródła Dziejowe, 12).

Polska XVI wieku pod względem geograficzno-statystycznym, oprac. A. Pawiński, t. 3: Małopolska, Warszawa 1886 (Źródła Dziejowe, 14).

Polska XVI wieku pod względem geograficzno-statystycznym, oprac. A. Pawiński, t. 5: Mazowsze, Warszawa 1886 ('́ródła Dziejowe, 16).

Polska XVI wieku pod względem geograficzno-statystycznym, oprac. A. Jabłonowski, t. 7, cz. 2, Ziemie Ruskie. Ruś Czerwona, Warszawa 1903 (Źródła Dziejowe, 18).

Rutkowski J., Co to byty folwarki w dawnej Polsce, RDSG, t. 3, 1934, s. 113-142.

Rybarski R., Handel i polityka handlowa Polski w XVI stuleciu, t. 1: Rozwój handlu i polityki handlowej, Warszawa 1928.

Szybkowski S., Kujawska szlachta urzędnicza w późnym średniowieczu (1370-1501), Gdańsk 2006.

Trzyna E., Ziemia sanocka i struktura jej własności feudalnej od połowy XVI do drugiej połowy XVII w., „Rocznik Województwa Rzeszowskiego” 9, 1978, s. 145-184.

Urban W., Skład społeczny i ideologia sejmiku krakowskiego w l. 1572-1606, PH, t. 44, 1953, z. 3, s. 309-331. 
Wyczański A., Studia nad folwarkiem szlacheckim w Polsce $w$ latach 1500-1580 , Warszawa 1960.

Wyczański A., Uwarstwienie społeczne w Polsce XVI wieku. Studia, Wrocław 1977.

Krzysztof Boroda

Petty nobility in the Polish Kingdom in the second half of the sixteenth century and its socio-economic importance

(Summary)

The purpose of the present article is to assess - throughout a statistical analysis of the information from tax registers of five provinces (voivodeships) - the importance of petty nobility within the social and economic structures of the noble estate in the Polish Kingdom at the end of the sixteenth century. In order to divide the noble estate into separate categories of wealth a criterion of estimated potential of the folwark (a form of manor farm) is used. Thus, the author regards as the petty nobility all noble landowners who personally cultivated their land regardless its area, and the peasant owners of maximum 5 lans (Polish: tan; Latin: laneus) (i.e. farms equalling folwark area up to ca. 4 lans). The land taxed by noblemen who had no serfs is regarded as no-peasant folwark (cultivated personally by the family of nobleman or with hired men and smallholders called zagrodnicy). For noblemen with serfs an assessment of their hypothetical folwark area has been made on the basis of taxed peasant land. The petty nobility thus defined predominated within the noble estate of the analysed provinces at the end of the sixteenth century, occasionally quite overwhelmingly. Its percentage in the total number of noble estates in the provinces was as follows: in the voivodeship of Cracow - 67 per cent, of Poznań - 68 per cent, of Kalisz - 80 per cent, of Łęczyca 92 per cent, and of Płock - 97 per cent. A strong economic domination of petty nobility was in the province of Płock, where those noblemen had 80 per cent of potential with a very high (20 per cent) percentage of noble estates comparable to those of peasant farms and based on personal cultivation of land. In the province of Łęczyca, among the petty nobility with almost 60 per cent of the total folwark land area most important was a group of noble farms of one to two lans. In the remaining three provinces (of Cracow, Poznań and Kalisz) folwarks belonging to petty noblemen were of secondary importance, as they had only 30-40 per cent of the total folwark area. However, their hypothetical acreage under cultivation was larger, as it usually equalled ca. 2.5 to 4 lans. 
Krzysztof Boroda - pracownik Instytutu Historii i Nauk Politycznych Uniwersytetu w Białymstoku oraz Instytutu Historii im. Tadeusza Manteuffla Polskiej Akademii Nauk. Zainteresowania badawcze: historia gospodarcza i społeczna Polski i Europy od schyłku antyku po nowożytność.

Krzysztof Boroda - employed at the Institute of History and Political Sciences, University of Bialystok, and Tadeusz Manteuffel Institute of History, Polish Academy of Sciences. His research interests include: economic and social history of Poland and Europe from the end of the antiquity to the early modern times.

E-mail:kbrda@wp.pl. 